\title{
Komunikasi Matematis Tulis Siswa pada Pembelajaran Inkuiri Terbimbing
}

\author{
${ }^{1}$ Chusnul Ma'rifah, ${ }^{2}$ Cholis Sa'dijah, ${ }^{3}$ Subanji \\ Jurusan Matematika FMIPA Universitas Negeri Malang \\ Jl. Semarang No.5, Sumbersari, Kec. Lowokwaru, Kota Malang, Jawa Timur, \\ Indonesia
}

Email: 1'chusnul.ma'rifah.1903117@student.um.ac.id, ${ }^{2}$ cholis.sadijah.fmipa@um.ac.id, ${ }^{3}$ subanji.fmipa@um.ac.id

\section{Tersedia Online di}

http://www.jurnal.unublitar.ac.id/ index.php/briliant

\section{Sejarah Artikel \\ Diterima pada Januari 2021 \\ Disetuji pada Mei 2021 \\ Dipublikasikan pada Mei 2021 \\ Hal. 363-375}

\section{Kata Kunci:}

Komunikasi Matematis Tulis;

Inkuiri Terbimbing

\section{DOI:}

http://dx.doi.org/10.28926/brilian t.v3i4.628

\begin{abstract}
Abstrak: Komunikasi matematis merupakan unsur penting dalam pembelajaran matematika. Penelitian deskriptif kualitatif ini bertujuan mendeskripsikan kemampuan komunikasi matematis tulis siswa pada lembar kerja siswa dengan model inkuiri terbimbing. Subjek diambil secara purposive sampling dan dipilih 10 siswa. Melalui observasi jawaban lembar aktivitas siswa, diperoleh tahapan analisis strategi mendapat persentase $100 \%$ yang berada pada katagori tinggi, sedangkan tahapan terendah adalah tahap pengajuan hipotesis dengan nilai 52,25\% yang berada pada katagori sedang. Pada tahapan analisis strategi, siswa sudah dapat merepresentasikan notasi matematis dan melakukan manipulasi matematis secara benar sehingga dapat menemukan rumus, sedangkan tahap pengajuan hipotesis, hipotesis yang dituliskan siswa belum benar dan akurat.
\end{abstract}

\section{PENDAHULUAN}

Matematika pada umumnya dinilai identik dengan perhitungan seputar angka dan rumus. Terdapat pula anggapan jika keterampilan komunikasi sulit dibangun dari pembelajaran matematika (Rohid dkk., 2019). Pernyataan ini bertentangan dengan fakta bahwa komunikasi matematika pada dasarnya merupakan keterampilan yang harus dimiliki dan sangat penting dalam pembelajaran, perannya pun sangat dibutuhkan (Sumaji dkk., 2020). Menurut NCTM (2000), komunikasi merupakan bagian esensial dari matematika dan pembelajaran matematika.

Pada umumnya, kemampuan komunikasi matematis menunjang kemampuan lainnya (Sumarmo, 2000). Kemampuan tersebut misalnya kemampuan penyelesaian masalah dan kemampuan representasi. Kemampuan komunikasi matematis juga berpengaruh pada pemahaman konseptual, pemecahan masalah, dan penalaran matematika (Sumaji dkk., 2020). Komunikasi matematis sebagai proses mengekspresikan dan memahami ide matematis, baik secara lisan, visual, 
dan tulisan. Ekspresi tersebut dapat menggunakan simbol, gambar, grafik, diagram, dan kata-kata (Walk dkk., 2005). Komunikasi juga penting dalam mengklarifikasi ide, sikap dan keyakinan tentang matematika, serta memperkuat dan memodifikasinya (Alberta, 2004).

Dalam praktik pembelajaran, seorang guru harus dapat memperhatikan aspek komunikasi dalam pembelajaran matematika. Aspek komunikasi matematis tersebut ada 5 yang meliputi mempresentasikan, mendengar, membaca, diskusi, dan menulis (Qohar \& Sumarmo, 2013). Dalam proses aspek-aspek tersebut, dibutuhkan interaksi antar siswa serta antara guru dengan siswa dan diantaranya dapat dilakukan dengan diskusi (Sarifatun, 2020). Guru juga harus dapat memilih bahan ajar yang dinilai memiliki kriteria praktis serta efektif yang menunjang komunikasi matematis (Ardina, 2016).

Lembar Kerja Siswa (LKS) merupakan salah satu bahan ajar yang sering digunakan dalam pembelajaran. LKS yang dirancang oleh guru dapat mengantarkan siswa dalam mempelajari dan mendalami konsep suatu materi (Ardina, 2016). LKS juga banyak digunakan yang berfungsi untuk beberapa tujuan, misalnya mendukung pembelajaran, meningkatkan pembelajaran agar lebih aktif, meningkatkan motivasi dalam belajar, juga dapat berfungsi sebagai bahan asesmen (Lee, 2014).

Lembar kerja siswa juga sebagai alat yang dapat mendukung kemampuan lain, termasuk kemampuan komunikasi matematis, khususnya secara tertulis. Kemampuan komunikasi matematis secara tertulis dapat diartikan sebagai kemampuan siswa dalam menerjemah serta mengorganisasikan pengetahuan menjadi susunan kalimat tertulis, sehingga pembaca dimudahkan untuk dapat memahami apa yang mereka maksud. Menulis dalam pembelajaran matematika dapat membantu siswa untuk menggabungkan dan memanggil kembali pemahaman yang didapat (NCTM, 2000). Dengan pemikiran ini serta adanya LKS sebagai bahan belajar, maka pencapaian akhir suatu pembelajaran dimungkinkan bukan hanya tentang pemahaman konsep, namun juga kemampuan komunikasi tulis yang memadai. Oleh karena itu, desain dan model LKS yang digunakan harus dapat menunjang dan mendukung kemampuan komunikasi matematis tulis.

Salah satu model pembelajaran yang dapat digunakan dalam LKS adalah inkuiri terbimbing. Sanjaya (Margunayasa. dkk, 2019) mengartikan pembelajaran inkuiri terbimbing sebagai rangkaian kegiatan pembelajaran yang menekankan proses berpikir secara kritis dan analitis secara mandiri untuk mencari dan menemukan jawaban yang sudah pasti dari suatu masalah yang ditanyakan. Sedangkan menurut (Romiyansah dkk., 2020) pembelajaran inkuiri terbimbing memberikan kesempatan siswa untuk membentuk pengetahuannya secara mandiri, karena menekankan pengalaman langsung dalam proses pembelajaran. Proses pembentukan pengetahuan selama pembelajaran inkuiri terbimbing tersebut dapat dilakukan melalui tanya jawab dan diskusi antara guru dan siswa maupun sesama siswa.

Inkuiri sendiri merupakan implememtasi dari pembelajaran konstekstual (Nurhadi \& Senduk, 2004), dimana pembelajaran kontekstual memiliki paham konstruktivis yang membelajarkan siswa untuk mempunyai kemampuan menghimpun pengetahuan sendiri. Pembelajaran konstruktivis merupakan pembelajaran yang bermakna karena dalam pembelajaran bermakna siswa 
mengkonstruksi pengetahuan lama dan menghubungkan dengan pengetahuan baru sehingga siswa memahami materi lebih dari sekedar tahu (Subanji, 2013). Sedangkan pembelajaran tak bermakna, mengisyaratkan proses konstruksi pengetahuan terjadi dimana pengetahuan lama tidak dikaitkan dengan pengetahuan baru yang bersifat sementara dan siswa cenderung lupa (Subanji, 2014).

Lahadisi (2014) menjelaskan ciri pembelajaran inkuiri terbimbing yaitu (1) strategi menekankan kepada aktivitas siswa secara maksimal untuk mencari dan menemukan, (2) menemukan sikap percaya diri (self belief) dengan penemuan yang ditemukan yang menempatkan guru bukan sebagai sumber belajar, akan tetapi sebagai fasilitator dan motivator belajar siswa, dan (3) mengembangkan kemampuan berpikir secara sistematis, logis, dan kritis, atau mengembangkan kemampuan intelektual sebagai bagian dari proses mental. Sedangkan keterampilan proses yang dikembangkan di dalam pembelajaran inkuiri ada dua, yaitu (1) keterampilan dasar yang meliputi observasi, komunikasi, klasifikasi, pengukuran, kesimpulan sementara, dan keterampilan prediksi serta (2) Keterampilan terintegrasi terdiri dari identifikasi variabel pembuatan tabel, pembuatan grafik, deskripsi hubungan antar variabel, data elisitasi dan pemrosesan, analisis investigasi, konstruksi hipotesis, variabel, definisi operasional, serta keterampilan investigasi dan desain eksperimen (Hardianti \& Kuswanto, 2017).

Tahapan model inkuiri terbimbing menurut Lieweliyin (Margunayasa dkk., 2019) ada enam, yaitu (1) inkuisisi, yaitu mulai dari pernyataan yang akan diselidiki, (2) akuisisi, yaitu memungkinkan prosedur brainstorming, (3) asumsi, mengidentifikasi pernyataan yang akan diuji, (4) implementasi, yaitu merancang dan melaksanakan rencana, (5) sumasi, yaitu mengumpulkan bukti dan menarik kesimpulan, dan (6) ekshibisi, yaitu berbagi dan mengkomunikasikan hasil. Sedangkan Trianto (2009) menjelaskan tahapan model pembelajaran inkuiri terbimbing yaitu: (1) menyajikan pertanyaan atau masalah, (2) menyajikan hipotesis atau dugaan awal, (3) merancang strategi/percobaan, (4) melakukan percobaan, (5) melakukan percobaan, (6) mengumpulkan sera menganalisis data dan (7) membuat kesimpulan.

Guru tidak mejelaskan materi secara verbal dan langsung selama pembelajaran dengan inkuiri terbimbing. Siswa dihadapkan pada masalah kemudian dapat melakukan penyelidikan sehingga diharapkan dapat menemukan sendiri materi yang diharapkan. Kegiatan mulai dari orientasi masalah sampai dengan penarikan kesimpulan dilakukan untuk menemukan konsep dan meningkatkan kemampuan komunikasi matematis. Komponen komunikasi matematis yang dikembangkan dari NCTM (2000) pada penelitian ini meliputi: (1) menyusun dan memadukan pemikiran matematis melalui komunikasi, (2) mengomunikasikan pemikiran matematis secara logis dan sistematis kepada sesama siswa, guru, maupun orang lain, dan (3) menggunakan bahasa matematis untuk menyampaikan ide matematis secara tepat.

Banyak penelitian yang telah dilakukan menggunakan pembelajaran inkuiri terbimbing. Ormanci dan Cepni (2020) mengemukakan jika pembelajaran dengan inkuiri terbimbing dapat meningkatkan keterampilan teknologi dan komunikasi siswa dalam bidang sains. Peningkatan keterampilan informasi dan komunikasi siswa tersebut, terutama terjadi pada proses pencarian, menemukan dan pemilihan 
informasi yang sesuai. Pembelajaran inkuiri terbimbing juga dapat meningkatkan kemampuan komunikasi siswa SMP pada materi phytagoras (Afifa, 2017). Serta menurut Hardianti dan Kuswanto (2017), secara umum pembelajaran inkuiri dapat meningkatkan keterampilan proses siswa.

Berdasarkan wawancara dengan praktisi matematika MA Mifda Kepanjen Malang diperoleh informasi jika kemampuan komunikasi matematis siswa kelas XI belum optimal. Salah satu penyebabnya adalah sumber belajar yang kurang memfasilitasi siswa berkomunikasi matematis. Diperkuat dengan diberikannya pretes dengan bentuk soal cerita kontekstual, diperoleh kemampuan matematis tulis siswa belum baik. Hampir semua siswa tidak menuliskan unsur apa yang diketahui dan ditanyakan pada soal. Siswa juga banyak yang belum menggunakan bahasa matematis dengan menggunakan simbol matematis dari masalah yang dihadapi, serta belum dapat mengekspresikan ide matematis secara tepat.

Kesimpulan hasil observasi, penelitian-penelitian tentang inkuiri terbimbing, serta temuan Afifa (2017) jika inkuiri terbimbing meningkatkan komunikasi matematis pada teorema pytagoras, maka LKS dengan model inkuiri terbimbing disusun pada materi barisan dan deret. Penyusunan ini dengan pertimbangan siswa dapat memahami konsep materi dengan penemuan dan dapat mengomunikasikan pemikiran matematis mereka. Dari LKS yang dibuat, akan diobservasi dan dideskripsikan jawaban siswa dan kemampuan komunikasi tulis mereka.

\section{METODE}

Jenis penelitian adalah penelitian kualitatif dan bersifat deskriptif yang bertujuan mendeskripsikan kemampuan komunikasi matematis tulis siswa pada LKS model inkuiri terbimbing pada materi barisan aritmatika dan geometri. Tujuan pembelajaran dengan LKS model inkuiri terbimbing ini adalah siswa dapat (1) mendefinisikan barisan aritmetika dan geometri, (2) menentukan rumus barisan aritmetika dan geometri melalui percobaan sederhana, dan (3) menemukan dan merepresentasikan rumus umum barisan aritmetika dan geometri dalam simbol matematis.

Subjek dalam penelitian ini adalah siswa MA Miftahul Huda Kepanjen Malang yang tersusun dalam kelompok. Pengelompokan ini digunakan sebagai setting kelas dengan menggunakan model kooperatif STAD, yaitu desain model pembelajaran kolaboratif yang didalamnya siswa terbagi menjadi beberapa kelompok kecil dengan kemampuan akademik berbeda yang bertujuan berbagi dalam pembelajaran (Santoso, 2019). Hal ini bertujuan agar materi pelajaran lebih mudah dipahami siswa, siswa pun menjadi lebih aktif, saling berdiskusi, bertanya, dan saling mengeluarkan pendapat (Diana, 2019).

Prosedur dalam penelitian ini yaitu 1) penyusunan instrumen, 2) pelaksanaan, dan 3) analisis data. Data penelitian yang akan diperoleh yaitu hasil observasi jawaban tertulis siswa pada LKS. Pada pengumpulan data digunakan observasi dan dokumentasi. Peneliti selaku observer mengamati hasil kerja siswa secara berkelompok pada Lembar Kerja Siswa (LKS). Instrumen atau alat pengambil data dalam penelitian ini adalah LKS yang telah divalidasi satu dosen matematika dan dua guru matematika.

366 BRILIANT: Jurnal Riset dan Konseptual Volume 6 Nomor 2, Mei 2021 
Sebelum siswa mengerjakan LKS, siswa diberikan pengantar materi dan aktivitas pada barisan aritmetika maupun geometri yang dapat dilihat pada Gambar 1 dan Gambar 2 berikut:

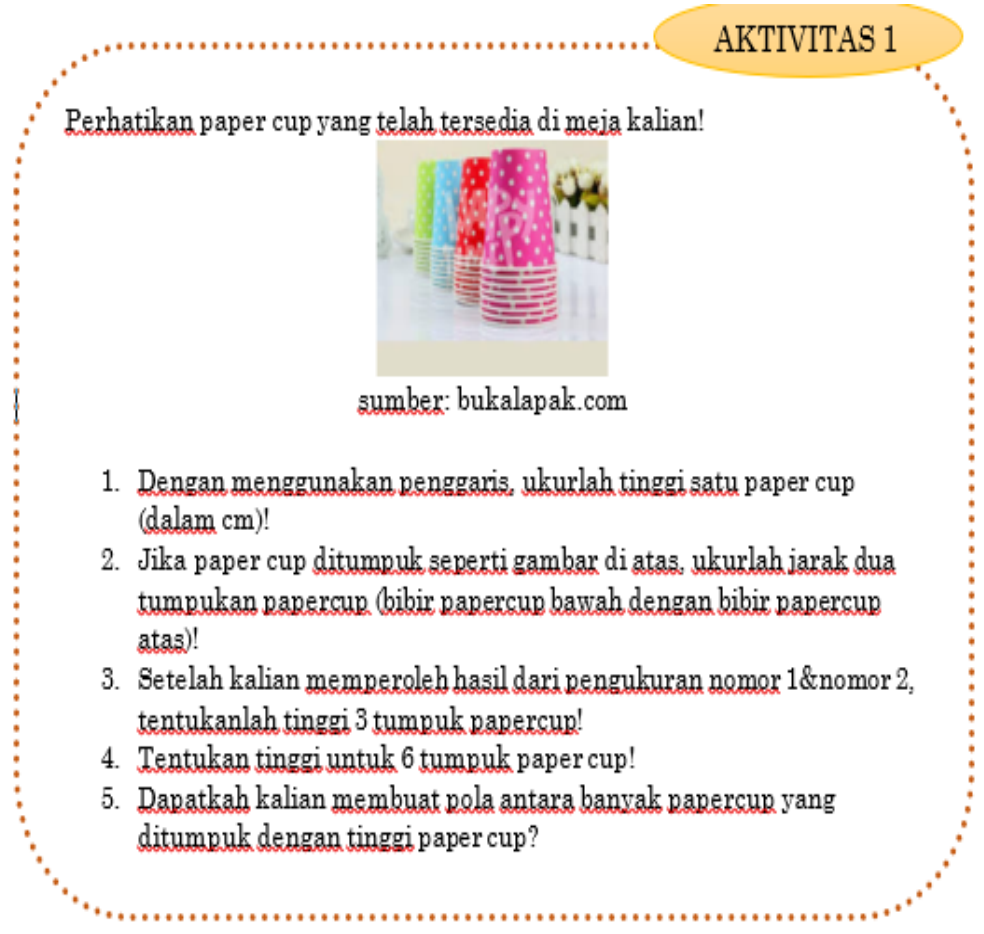

Gambar 1. Aktivitas Awal Materi Barisan Aritmetika

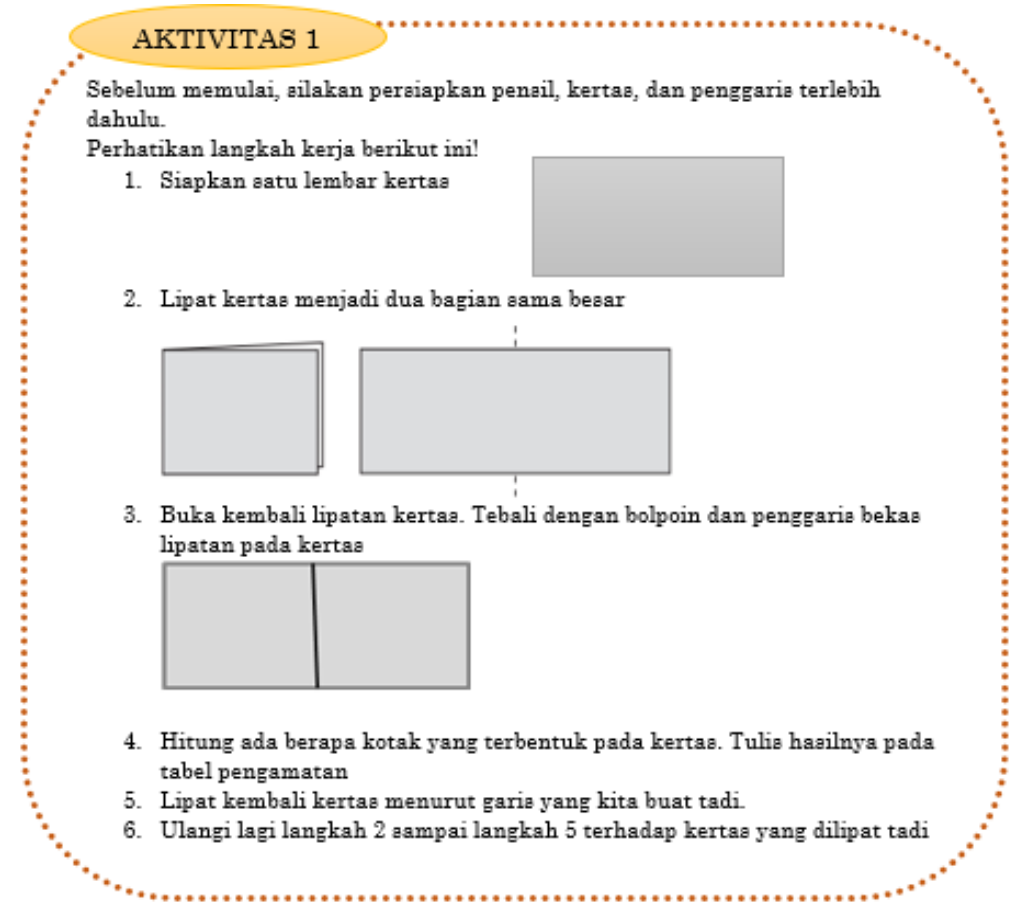

Gambar 2 . Aktivitas Awal Materi Barisan Geometri 
Setelah diberikan aktivitas awal, selanjutnya LKS menyajikan aktivitas dengan langkah pembelajaran inkuiri sesuai tujuan pembelajaran. Langkah inkuiri menggunakan perpaduan langkah inkuiri digunakan oleh Lieweliyin (Margunayasa dkk., 2019) dan Trianto (2009). Langkah-langkah yang digunakan yaitu: (1) menyajikan pertanyaan atau masalah, (2) menyusun dugaan/hipotesis, (3) merancang strategi/percobaan, (4) melakukan strategi/percobaan, (5) mengumpulkan dan menganalisis data, dan (6) menarik kesimpulan.

Pada penelitian ini, digunakan indikator komunikasi matematis tulis siswa yang dikembangkan dari komponen komunikasi matematis menurut NCTM (2000). Indikator dapat dilihat pada Tabel 1 berikut ini.

Tabel 1. Indikator Komunikasi Matematis Tulis dalam LKS dengan Model Inkuiri Terbimbing

\begin{tabular}{|c|c|c|}
\hline No & $\begin{array}{l}\text { Langkah LKS dengan } \\
\text { Inkuiri terbimbing }\end{array}$ & Indikator Komunikasi Matematis Tulis yang Dikembangkan \\
\hline 1 & Identifikasi Masalah & $\begin{array}{l}\text { - Menuliskan hal-hal yang diketahui dari masalah } \\
\text { - } \quad \text { Menuliskan apa yang ditanyakan dalam masalah } \\
\end{array}$ \\
\hline 2 & Menggali Hipotesis & Menuliskan dugaan yang mungkin dari selesaian masalah \\
\hline 3 & $\begin{array}{l}\text { Merancang } \\
\text { strategi/percobaan }\end{array}$ & $\begin{array}{l}\text { - Menulis barisan bilangan sementara dari masalah yang } \\
\text { disajikan } \\
\text { - Membuat gambar/sketsa jika diperlukan }\end{array}$ \\
\hline 4 & $\begin{array}{l}\text { Melakukan } \\
\text { percobaan/strategi }\end{array}$ & $\begin{array}{l}\text { Menuliskan langkah-langkah dengan memulai perhitungan } \\
\text { secara benar, lengkap, dan akurat dari masalah secara spesifik }\end{array}$ \\
\hline 5 & Menganalisa strategi & $\begin{array}{l}\text { Menganalisa strategi dengan manipulasi matematis dalam } \\
\text { menuliskan simbol/notasi matematis secara umum sehingga } \\
\text { dapat menemukan dan merepresentasikan konsep/rumus yang } \\
\text { benar }\end{array}$ \\
\hline 6 & $\begin{array}{l}\text { Menuliskan } \\
\text { kesimpulan }\end{array}$ & $\begin{array}{l}\text { Menuliskan kesimpulan dari konsep yang diperoleh berdasarkan } \\
\text { temuan masalah dan selesaian }\end{array}$ \\
\hline
\end{tabular}

Teknik pengolahan data diadaptasi dari Sumarmo (Wijayanto dkk., 2018) yang disajikan pada Tabel 2 dan Tabel 3.

Tabel 2. Pedoman Penskoran Kemampuan Komuniksi Matematis

\begin{tabular}{cl}
\hline Skor & \multicolumn{1}{c}{ Kriteria } \\
\hline 4 & Respon lengkap, benar dan jelas, sajian rumus dan perhitungan lengkap dan logis \\
3 & Respon benar atau jelas, sajian rumus dan perhitungan lengkap. \\
2 & Respon tidak benar atau tidak jelas, sajian rumus atau perhitungan kurang lengkap \\
1 & Respon tidak benar dan tidak jelas, sajianrumus dan perhitungan kurang tepat \\
0 & Respon tidak efisien, missinterpretasi (tidak ada jawaban apapun/lembar jawaban \\
& siswa kosong)
\end{tabular}

(Adaptasi dari Wijayanto dkk., 2018)

Tabel 3. Katagori Pencapaian Kemampuan Komunikasi Matematis Siswa.

\begin{tabular}{cc}
\hline Pencapaian Komunikasi Matematis $(\%)$ & Kategori \\
\hline $0-33$ & Rendah \\
$65-34$ & Sedang \\
$66-100$ & Tinggi \\
\hline
\end{tabular}

(Wijayanto dkk., 2018)

368 BRILIANT: Jurnal Riset dan Konseptual Volume 6 Nomor 2, Mei 2021 


\section{HASIL DAN PEMBAHASAN}

Pelaksanaan penelitian dilaksanakan pada tanggal 1 Oktober 2020 sampai dengan 8 Oktober 2020 dengan dua kali pertemuan. Penelitian ini berlangsung dalam masa pandemi dan partisipan sebanyak 10 siswa yang terbagi menjadi dua kelompok. Pembagian tersebut berdasarkan perolehan hasil skor pretes yang dilaksanakan sehari sebelum pembelajaran. Kerja kelompok dilakukan dengan memperhatikan protokol kesehatan.

Setelah pembelajaran dengan menggunakan LKS model inkuiri terbimbing, diperoleh data berupa nilai kemampuan komunikasi matematis siswa berdasar indikator dan acuan pedoman penskoran yang ditetapkan. Data tersebut dapat dilihat pada Tabel 4 berikut.

Tabel 4. Perolehan Nilai tiap kelompok pada Tahapan Inkuiri Materi Barisan Aritmetika dan Geometri beserta Katagorinya

\begin{tabular}{|c|c|c|c|c|c|c|c|c|c|}
\hline $\mathrm{N}$ & Tahapan & & san Aritr & tika & & isan Geor & etri & Rata- & Kata- \\
\hline o & & $\begin{array}{c}\text { Rata- } \\
\text { rata }\end{array}$ & $\begin{array}{c}\text { Prosen- } \\
\text { tase }\end{array}$ & $\begin{array}{c}\text { Kata- } \\
\text { gori }\end{array}$ & $\begin{array}{c}\text { Rata- } \\
\text { rata }\end{array}$ & $\begin{array}{c}\text { Prosen- } \\
\text { tase }\end{array}$ & $\begin{array}{c}\text { Kata- } \\
\text { gori }\end{array}$ & rata & gori \\
\hline 1 & $\begin{array}{l}\text { Identifikasi } \\
\text { Masalah }\end{array}$ & 3 & $75 \%$ & Tinggi & 3 & $75 \%$ & tinggi & 3 & Tinggi \\
\hline 2 & $\begin{array}{l}\text { Perumusan } \\
\text { Hipotesis }\end{array}$ & 2,5 & $62,5 \%$ & Sedang & 2 & $50 \%$ & Sedang & 2,25 & Sedang \\
\hline 3 & $\begin{array}{l}\text { Merancang } \\
\text { Strategi/ } \\
\text { Percobaan }\end{array}$ & 2,5 & $62,5 \%$ & Sedang & 4 & $100 \%$ & Tinggi & 3,25 & Tinggi \\
\hline 4 & $\begin{array}{l}\text { Melakukan } \\
\text { Strategi/ } \\
\text { Percobaan }\end{array}$ & 3,5 & $87,5 \%$ & Tinggi & 4 & $100 \%$ & Tinggi & 3,75 & Tinggi \\
\hline 5 & $\begin{array}{l}\text { Analisis } \\
\text { Strategi/ } \\
\text { percobaan }\end{array}$ & 4 & $100 \%$ & Tinggi & 4 & $100 \%$ & Tinggi & 4 & Tinggi \\
\hline 6 & $\begin{array}{l}\text { Kesimpu- } \\
\text { lan }\end{array}$ & 3,5 & $87,5 \%$ & Tinggi & 3 & $75 \%$ & Tinggi & 3,25 & Tinggi \\
\hline
\end{tabular}

Berdasarkan Tabel 4 di atas, diperoleh skor tertinggi adalah ketika siswa melakukan analisis strategi/percobaan sedangkan skor terendah adalah ketika siswa menuliskan hipotesis. Berikut adalah deskripsi hasil jawaban siswa dari tiap langkah inkuiri.

1. Tahap Identifikasi Masalah

Pada materi barisan aritmatika, langkah awal siswa adalah mengamati masalah sesuai pada Gambar 1. Secara umum kedua kelompok sudah dapat memberikan respon yang jelas. Indikator sudah dipenuhi siswa dengan menuliskan hal-hal yang diketahui dan ditanyakan berdasarkan aktivitas 1 . Mereka sudah dapat menuliskan hal yang diketahui, yakni tinggi satu papercup dan selisih antara dua bibir papercup secara bertumpuk. Namun pada satu kelompok siswa belum dapat menuliskan masalah apa yang dihadapi dimana siswa seharusnya menuliskan masalah mencari pola antara tinggi papercup dengan banyak papercup yang menyusun. Sedangkan pada materi barisan geometri, kedua kelompok siswa sudah dapat menuliskan hal-hal yang diketahui 
dan serta merumuskan masalah dari aktivitas 1, namun bahasa yang digunakan ada yang belum dapat dipahami.

2. Tahap Penyusunan Hipotesis

Pada materi barisan aritmetika, secara umum siswa dapat mengungkapkan dugaan awal berupa jawaban masalah mencari tinggi pepercup dengan sejumlah tumpukan sesuai masalah pada LKS. Akan tetapi, siswa belum dapat menuliskan hipotesis bagaimana selesaian masalah mencari tinggi papercup dengan sejumlah tumpukan bebas ( $n$ tumpukan) sebagai generalisasi awal. Jawaban yang diharapkan pada tahapan ini adalah siswa dapat menuliskan dugaan adanya keterkaitan antara banyak tumpukan papercup dengan ketinggiannya dalam bentuk rumus.

Pada materi barisan geometri, jawaban yang diharapkan adalah ditemukannya kaitan antara banyak lipatan $(n)$ dengan banyak daerah yang terbentuk, yaitu sebanyak $2^{n}$. Dugaan yang dituliskan kedua kelompok adalah banyak cara mencari daerah hasil lipatan sebanyak $2^{n}$, hanya saja penjelasan masalah dengan kaitan $2^{n}$ belum dijelaskan.

3. Tahap Merancang Strategi/Percobaan

Pada barisan aritmetika siswa dapat menuliskan barisan bilangan sebagai representasi tinggi papercup dari $n$ papercup. Siswa juga dapat menuliskan suku pertama dan beda barisan tersebut. Hasil barisan bilangan yang diperoleh pada tahap ini, digunakan sebagai dasar untuk menganalisa keterkaitan bilangan dengan rumus fungsi tinggi papercup dengan $n$ tumpukan. Pada materi barisan geometri, langkah merancang percobaan ini langsung menjadi kesatuan dengan langkah melakukan strategi/percobaan.

4. Tahap Melakukan Strategi/Percobaan

Pada barisan aritmetika, siswa melakukan percobaan langsung dengan melakukan pengukuran sesuai langkah-langkah yang diarahkan guru. Siswa sudah dapat merepresentasikan hasil pengukuran mereka pada tinggi papercup, lalu menyatakan persamaan tinggi papercup tersebut dalam rumus secara umum. Pada materi barisan geometri, siswa melakukan langkah ini dengan melakukan pengisian tabel sebagai representasi banyak daerah hasil dari lipatan kertas. Melalui sajian dari tabel siswa diharapkan dapat menebak pola yang terbentuk, sehingga dapat mengetahui persamaan banyak daerah lipatan dengan lipatan yang dilakukan.

5. Tahap Menganalisis Strategi/Percobaan

Tahap ini adalah tahap dimana siswa dapat menggeneralisasi rumus umum berdasar masalah dan aktivitas yang dilakukan dari tahap inkuiri. Siswa dapat menemukan rumus umum barisan aritmetika maupun geometri dengan manipulasi matematis yang dibantu oleh guru. Tahap ini cenderung banyak berfokus pada penulisan simbol matematis umum. Siswa telah dapat mengaitkan aktivitas yang telah dilakukan sebelumnya dengan untuk mendapatkan simbol suku awal $(a)$, beda $(b)$, rasio $(r)$, dan suku ke n $(U n)$ untuk menemukan rumus umum barisan aritmetika dan rumus umum barisan geometri.

6. Tahap Menarik Kesimpulan

Kesimpulan yang dituliskan siswa beragam. Pada barisan aritmetika, satu kelompok siswa menuliskan kesimpulan secara lengkap meliputi pengertian dan 
rumus barisan aritmetika, namun kelompok lain hanya menuliskan rumus barisan aritmetika tanpa pengertian. Rumus tersebut juga masih dikaitkan dengan masalah pada aktivitas sebelumnya sehingga seolah tidak berlaku secara umum. Adapun pada barisan geometri, satu kelompok sudah benar dan jelas dalam menuliskan pengertian dan rumus umum barisan geometri, namun kelompok yang lain hanya menuliskan rumus umum barisan geometri, dan masih dikaitkan dengan masalah pelipatan kertas.

Dari tiap tahapan LKS dengan model inkuiri terbimbing di atas, dapat dilihat jika pada tahap identifikasi masalah secara umum siswa sudah dapat menuliskan apa yang diketahui dan ditanyakan dari masalah baik dengan menggunakan katakata maupun dengan notasi matematis. Penulisan ini sangatlah penting dilakukan di awal kegiatan karena sebagai orientasi dasar terhadap masalah. Dengan melakukan orientasi terhadap masalah, berarti siswa sudah mengenal dan paham tentang apa yang harus diselesaikan pada masalah (Lindawati, 2011). Orientasi dan identifikasi masalah juga akan dapat membuat siswa dapat mendefinisikan masalah yang menjadi pokok penelitian atau hal yang harus diselesaikan.

Pada tahap mengajukan hipotesis, komunikasi matematis yang dilakukan berada pada katagori sedang dengan nilai 56,25\% dan mempunyai nilai terendah. Dari jawaban, terlihat jika siswa masih belum begitu baik dalam menuliskan dugaan sementara dari selesaian masalah yang dihadapi. Siswa belum ada yang mengungkapkan gagasan matematis mereka tentang dugaan rumus umum barisan dan masih sebatas menulis dugaan rumus dari masalah yang dihadapi.

Tahap merancang dan melakukan strategi/percobaan, siswa sudah dapat menuliskan barisan bilangan sementara yang dibentuk dari masalah, kemudian menggali unsur apa yang terdapat pada barisan tersebut, yakni suku awal dan beda. Siswa dapat menuliskan langkah-langkah dengan memulai perhitungan dengan tepat sesuai masalah. Tahap melakukan strategi ini penting, karena sebagai langkah awal untuk menemukan dan merepresentasikan generalisasi rumus sesuai masalah. Pemahaman siswa tentang masalah pada tahap identifikasi juga berpengaruh, dikarenakan apabila kemampuan pemahaman rendah, maka kompetensi strategis juga rendah. Kompetensi strategis diartikan suatu keterampilan untuk menyelesaikan masalah matematika, yaitu menggunakan strategi yang tepat untuk menyelesaikan masalah dengan merumuskan, mempresentasikan agar mendapatkan solusi yang tepat (Wijayanti dkk., 2020)

Pada tahap analisis terdapat banyak manipulasi matematis terhadap notasi dan simbol matematis. Manipulasi notasi dan simbol matematis yang dilakukan bertujuan agar siswa dapat menemukan rumus barisan aritmetika dan geometri. Daya kreatif dan disposisi matematis siswa diutamakan pada tahap ini, sehingga scaffolding guru banyak diperlukan. Hal ini dikarenakan tidak semua siswa memahami bagaimana melakukan manipulasi matematis dan fungsinya. Setelah siswa menemukan rumusan akhir, baru mereka memahami jika langkah yang dilakukan ini adalah bertujuan untuk menemukan rumus umum barisan aritmetika dan geometri. Menurut Retnodari, dkk (2020), pemberian scaffolding guru sangat berperan dalam membantu proses pembelajaran dikarenakan dapat memberikan keterampilan bagi siswa, siswa lebih mandiri, dan motivasi lebih meningkat. 
Disamping itu, tidak semua siswa terbiasa melakukan manipulasi matematis sebab tidak semua dari mereka mempunyai strategi untuk memecahkan persoalan matematika (Wijayanti dkk., 2020).

Komunikasi siswa pada tahap menarik kesimpulan berada pada katagori baik. Mereka sudah dapat menuliskan kesimpulan dari konsep yang ditemukan, walaupun ada satu kelompok yang masih belum dapat menuliskan dengan lengkap. Menurut Pugalee (Qohar \& Sumarmo, 2013) siswa harus didorong untuk dapat mengomentari pernyataan matematis dengan bahasa mereka sendiri. Hal ini dikarenakan tahap ini adalah tahap generalisasi sekaligus verifikasi dari semua proses yang mereka lakukan. Jika kesimpulan yang dituliskan belum tepat, maka harus ada yang perlu diperbaiki dari proses yang dilakukan.

Secara umum kemampuan komunikasi matematis siswa dapat meningkat dengan LKS model inkuiri terbimbing ini. Selain komunikasi matematis, pembelajaran inkuiri juga dapat meningkatkan disposisi berpikir matematis siswa (Sefalianti, 2014) dimana disposisi matematis sangat berpengaruh terhadap kemampuan komunikasi matematis (Diningrum dkk., 2018). Menurut Clark (dalam Qohar \& Sumarmo, 2013), kemampuan komunikasi efektif harus dimiliki oleh siswa tidak hanya dalam matematika, sebab seseorang yang cenderung memiliki kemampuan komunikasi yang baik, maka akan mampu bekerjasama dengan masyarakat dan berkesempatan menjadi orang yang sukses.

Pembelajaran dengan LKS model inkuiri terbimbing juga relevan dengan teori belajar bruner, yang terkenal dengan sebutan belajar penemuan (Fatmariani dkk., 2015). Teori ini tediri dari empat hal pokok, yaitu pertama individu akan belajar dan mengembangkan pikiran jika dia menggunakan pikirannya. Kedua, dalam belajar proses kognitif dengan penemuan, siswa akan memperoleh kepuasan intelektual sebagai suatu penghargaan intrinsik. Ketiga, satu-satunya cara agar siswa dapat mempelajari teknik-teknik penemuan adalah dengan mempunyai kesempatan menemukan. Yang terakhir, dengan melakukan penemuan maka akan memperkuat retensi ingatan.

\section{KESIMPULAN}

Komunikasi matematis siswa dari setiap tahapan inkuiri terbimbing secara umum sudah bagus. Komunikasi siswa yang paling baik ketika siswa berada pada tahap analisis strategi/percobaan dengan nilai 100\%, dimana scaffolding guru sangat berperan sehingga siswa dapat menemukan rumus barisan aritmetika maupun geometri dengan notasi matematis secara benar. Adapun tahapan yang masih perlu ditingkatkan adalah tahap perumusan hipotesis/dugaan selesaian masalah yang mendapatkan nilai 56,25\% dimana siswa masih belum dapat menuliskan hipotesis masalah dengan sepenuhnya benar dan akurat. LKS dengan model inkuiri terbimbing ini dapat meningkatkan disposisi matematis siswa terutama pada tahap melakukan analisis strategi.

\section{SARAN}

Bimbingan guru sangat diperlukan ketika siswa mengerjakan LKS dengan model inkuiri terbimbing agar mereka dapat mengomunikasikan ide dan pemikiran matematis dengan baik. Masalah yang disajikan dan pertanyaan-pertanyaan yang dirancang guru secara tertulis pada LKS, dapat disusun lebih baik agar siswa lebih 
aktif mengemukakan ide matematis secara tertulis. Berikutnya, dapat dikaji sejauh mana penaruh disposisi matematis pada kemampuan komunikasi matematis, khususnya komunikasi matematis tulis.

\section{DAFTAR RUJUKAN}

Afifa, F. M. (2017). Meningkatkan Kemampuan Komunikasi Matematis Siswa kelas VIII B SMP Negeri 3 Kota Mojokerto Melalui metode pembelajaran Penemuan Terbimbing pada Materi Teorema Pythagoras. Tesis tidak diterbitkan. Malang: Pascasarjana Universitas Negeri Malang.

Alberta. (2004). Focus on Inquiry. Alberta Education.

Ardina, F. R. (2016). Analisis Lembar Kerja Siswa dalam Meningkatkan Komunikasi Matematis Tulis Siswa. Jurnal PEndidikan: Teori, Penelitian, Dan Pengembangan, 1(2), 171-180.

Diana, T. A. (2019). Pengaruh Model Pembelajaran Student Team Achievement Division (STAD) Terhadap Kemampuan Komunikasi Matematis Peserta Didik SMPN 17 Kota Bengkulu. Seminar Nasional Tadris (Pendidikan) Matematika, 45-48.

Diningrum, P. R., Azhar, E., \& Faradillah, A. (2018). hubungan disposisi matematis terhadap kemampuan komunikasi matematis siswa kelas VII di SMP Megeri 24 Jakarta. Seminar Nasional Pendidikan Matematika 2018, 01, 352-364.

Fatmariani, Ismail, M. I., \& Abrar, P. (2015). Perbandingan Kemampuan Komunikasi Matematis Dengan Menggunakan Pendekatan Inkuiri Terbimbing Dan Pendekatan Saintifik Siswa Kelas Vii Di Smp Wahyu Makassar. Matematika Dan Pembelajran, 3(2), 149-162. http://journal.uinalauddin.ac.id/index.php/Mapan/article/view/3138

Hardianti, T., \& Kuswanto, H. (2017). Difference among levels of inquiry: Process skills improvement at senior high school in Indonesia. International Journal of Instruction, 10(2), 119-130. https://doi.org/10.12973/iji.2017.1028a

Lahadisi. (2014). Inkuiri : Sebuah Strategi Menuju Pembelajaran Bermakna. Jurnal Al-Ta'dib Vol. 7 No. 2 Juli-Desember, 7(2), 85-98.

Lee, C.-D. (2014). Worksheet Usage, Reading Achievement, Classes' Lack of Readiness, and Science Achievement: A Cross-Country Comparison. International Journal of Education in Mathematics, Science and Technology, 2(2). https://doi.org/10.18404/ijemst.38331

Lindawati, S. R. I. (2011). Pembelajaran Matematika dengan Pendekatan Inkuiri Terbimbing untuk Meningkatkan Kemampuan Pemahaman Dan Komunikasi Matematis Siswa Sekolah Menengah Pertama. Jurnal Pendidikan, 2(2), 1629.

Margunayasa, I. G., Dantes, N., Marhaeni, A. A. I. N., \& Suastra, I. W. (2019). The effect of guided inquiry learning and cognitive style on science learning achievement. International Journal of Instruction, 12(1), 737-750. https://doi.org/10.29333/iji.2019.12147a

Mathematics, N. C. of T. of. (2000). Principles Standards and for School Mathematics. NCTM.

Nurhadi, \& Senduk. (2004). Pembelajaran Kontekstual dan Penerapannya dalam $K B K$. Malang: UM Press. Universitas Negeri Malang. 
Ormanc1, Ü., \& Çepni, S. (2020). Investigating the Effects of Web-Based Science Material for Guided Inquiry Approach on Information and Communication Skills of Students. Participatory Educational Research, 7(1), 201-219. https://doi.org/10.17275/per.20.12.7.1

Qohar, A., \& Sumarmo, U. (2013). Improving mathematical communication ability and self regulation learning of yunior high students by using reciprocal teaching. Journal on Mathematics Education, 4(1), 59-74. https://doi.org/10.22342/jme.4.1.562.59-74

Retnodari, W., Elbas, Wi. F., \& Selvi, L. (2020). Scaffolding dalam Pembelajaran Matematika. LINEAR: Journal of Mathematics Education, 1(1), 15-21.

Rohid, N., Suryaman, S., \& Rusmawati, R. D. (2019). Students' Mathematical Communication Skills (MCS) in Solving Mathematics Problems: A Case in Indonesian Context. Anatolian Journal of Education, 4(2), 19-30. https://doi.org/10.29333/aje.2019.423a

Romiyansah, R., Karim, K., \& Mawaddah, S. (2020). Analisis Kemampuan Koneksi Matematis Siswa Pada Pembelajaran Matematika Dengan Menggunakan Model Pembelajaran Inkuiri Terbimbing. EDU-MAT: Jurnal Pendidikan Matematika, 8(1), 88-95. https://doi.org/10.20527/edumat.v8i1.8342

Santoso, R. A. (2019). Pengaruh Model Pembelajaran Kooperatif Tipe Student Team Achievement Division (STAD) Terhadap Hasil Belajar PKn Siswa kelas $V$ SDN 10 Metro timur. Tesis tidak diterbitkan. Lampung: Universitas Lampung.

Sarifatun, I. (2020). Kemampuan Komunikasi Matematis Siswa Kelas Vii Smp Negeri 1 Mojolaban. IAIN Purwokerto.

Sefalianti, B. (2014). Penerapan Pendekatan Inkuiri Terbimbing Terhadap Kemampuan Komunikasi dan Disposisi Matematis Siswa. Jurnal Pendidikan Dan Keguruan, 1(2), 209697.

Subanji. (2013). Revitalisasi Pembelajaran Bermakna dan Penerapannya Dalam Pembelajaran Matematika Sekolah. Seminar Nasional TEQIP, 2013, 685-693.

Subanji, S. (2014). TEQIP sebagai Wahana Mewujudkan Pembelajaran Bermakna dan Membangun Karakter Bangsa. J-Teqip, 5(2), 307-318.

Sumaji, Sa'Dijah, C., Susiswo, \& Sisworo. (2020). Mathematical communication process of junior high school students in solving problems based on APOS theory. Journal for the Education of Gifted Young Scientists, 8(1), 197-221. https://doi.org/10.17478/jegys.652055

Sumarmo. (2000). Pengembangan Model Pembelajaran Matematika untuk Meningkatkan Kemampuan Intelektual Tingkat Tinggi Siswa Sekolah Dasar.

Trianto. (2009). Mendesain Model Pembelajaran Inovatif-Progresif: Konsep, Landasan, dan Implementasinya pada Kurikulum Tingkat Satuan Pendidikan $(K T S P)$. Jakarta: Kencana.

Walk, G., Congress, M., \& Bansho. (2005). Communication in mathematics classrooms. Mathematics Education: Exploring the Culture of Learning, 8490, 117-119. https://doi.org/10.4324/9780203465394

Wijayanti, A., Ah, N. I., \& Kusuma, Y. D. (2020). Analisis Kompetensi Strategis Matematis Siswa dalam Memecahkan Soal Matematika. Jember.

Wijayanto, A. D., Fajriah, S. N., \& Anita, I. W. (2018). Analisis Kemampuan 
Komunikasi Matematis Siswa Smp Pada Materi Segitiga Dan Segiempat. Jurnal Cendekia: Jurnal Pendidikan Matematika, 2(1), 97-104. https://doi.org/10.31004/cendekia.v2i1.36 